Infusionsther Transfusionsmed 1995;22:329

\title{
Inhalt, Vol. 22, No. 6, 1995
}

\section{Contents}

Editorial

Zytokininduktion durch kolloidale Plasmaersatzmittel?

\section{Krombach, F.}

\section{Editorial}

Cytokine Release by Colloidal Plasma Substitutes?

330 Krombach, F.

330

\section{Originalarbeiten}

Der Einfluß kolloidaler Plasmaersatzmittel auf die Freisetzung von Tumor-Nekrose-Faktor-alpha $(\mathrm{TNF}-\alpha)$ in menschlichem Vollblut in vitro

Sirtl, C, Salewsky, G., Baier, J., Lange, S., Laubenthal, H.,

Neumann, H. A 332

Vergleich zwischen berechneter und gemessener gemischt-venöser Sauerstoffsättigung bei

Schwerstkranken

Cieslinski, G., Konrad, T., Klepzig, H 340

Durchflußzytofluorometrischer Nachweis von erythrozytären Antigenen und Antíkörpern

Fischer, K., Wester, S., Grundmann, A., Poschmann, A 344

Der posttransfusionelle Thrombozytenanstieg: Beobachtungen an einem hämatologisch-

onkologischen Patientengut

Böck. M., Muggenthaler, K. H., Schmidt, U, Heim, M. U,,

Mempel, W. 350

Praktikabilität und Effektivität der Leukozytendepletion mit einem Leukozytendepletionsfilter bei Massivtransfusion

Rieger, A.. Saefkow, M., Haß, F, Spies, C, Eyrich. K

IgG-Subklassenverteilung in IVIG-Produkten: Ermittlung der Repro-duzierbarkeit einer

Methode der IgG-Subklassenbestimmung

Kotitschke, R., Lang, H., Page, M 360

Original Paper

The Influence of Colloidal Plasma Substitutes on the Release of Tumor Necrosis Factor alpha

(TNF- $\alpha$ ) in Human Whole Blood in vitro

Sirtl, C, Salewsky, G, Baier, J., Lange, S., Laubenthal, FT.,

Neumann, H. A 332

Comparison of Calculated and Measured Mixed Venous Oxygen Saturation in Critically Ill

Patients

Cieslinski, G, Konrad, T., Klepzig, H340

Flow Cytometric Analysis of Red Cell Antigens and Antibodies

Fischer, K, Wester, S., Grundmann. A., Poschmann, A 344

Clinical Conditions Influencing Posttransfusional Platelet Increment 
Böck, M., Muggenthaler, K. H., Schmidt, LI,

Heim, M. U, Mempel, W. 350

Feasibility and Rate of Leucocyte Depletion with a Single Leucocyte Depletion Filter during Massive Transfusion

Rieger, A., Saefkow, M., Haß, F, Spies, C, Eyrich, K 355

IgG Subclass Distribution in IVIG Products: Assessment of the Repro-ducibility of a Method for the Determination of IgG Subclasses

Kotitschke, R., Fang, H., Page, M 360

Qualitätsmanagement

Aufbau eines Qualitätssicherungssystems in der Transfusionsmedizin am Beispiel der Universitätsblutbank Heidelberg

Stahl, D., Kluge, A., Roelcke. D

Quality Management

Establishment of a Quality Assurance System in Transfusion Medicine Exemplarily Shown for the University Blood Bank at Heidelberg

Stahl, D., Kluge, A., Roelcke, D 364

Kommentar

Zum Votum des Arbeitskreises Blut «Empfehlung zu Bestellung und Aufgaben von Transfusionsverantwortlichen, Transfusions-beauftragten, Transfusionskommissionen und Arbeitskreisen für Hämotherapie»: Erläuterungen und Vorschläge zur Umsetzung Hanfland, P., Götz, E., Kretschmer, V. 379

Impressum 328

Dank an die Gutachter $\quad 384$

Autorenverzeichnis $1995 \quad 385$

Sachwortregister $1995 \quad 387$

Jahres-Inhalt $1995 \quad$ Ill (nach 390)

Hinweise für Autoren 2. und 3. Umschlagseite

Commentary

Commentary Concerning the Vote of the Arbeitskreis Blut 'Transfusion Commissions, Working

Groups on Haemotherapy, and Persons Who Are Responsible for and Entrusted with

Transfusions': Recommendations to Their Appointment and Assignment of Tasks

Hanfland, P., Götz, E., Kretschmer, V. 379

Imprint328

Acknowledgements to the Reviewers 384

Author Index $1995 \quad 385$

Subject Index $1995 \quad 389$

Complete Contents 1995 VI (following 390)

Instructions to Authors cover pages 2 and 3 